medRxiv preprint doi: https://doi.org/10.1101/2021.01.12.21249649; this version posted August 5, 2021. The copyright holder for this preprint (which was not certified by peer review) is the author/funder, who has granted medRxiv a license to display the preprint in It is made available under a CC-BY 4.0 International license.

\title{
Using Mendelian randomisation to explore the gateway hypothesis: Possible causal effects of smoking initiation and alcohol consumption on substance use outcomes
}

Zoe E. Reed ${ }^{1,2}$, Robyn E. Wootton ${ }^{2,3}$, Marcus R. Munafò̀ ${ }^{1,2,4}$

1 School of Psychological Science, University of Bristol, Bristol, UK

2 MRC Integrative Epidemiology Unit, University of Bristol, Bristol, UK

3 Nic Waals Institute, Lovisenberg Diaconal Hospital, Oslo, Norway.

4 National Institute for Health Research Bristol Biomedical Research Centre, University Hospitals Bristol NHS Foundation Trust and University of Bristol, Bristol, UK

Running head: MR and the gateway hypothesis

Word count: 4,020

Declarations of interest: The authors have no conflicts of interest to declare. 
medRxiv preprint doi: https://doi.org/10.1101/2021.01.12.21249649; this version posted August 5, 2021. The copyright holder for this preprint (which was not certified by peer review) is the author/funder, who has granted medRxiv a license to display the preprint in It is made available under a CC-BY 4.0 International license.

\begin{abstract}
Background and Aims:

Initial use of drugs such as tobacco and alcohol may lead to subsequent more problematic drug use - the 'gateway' hypothesis. However, observed associations may be due to a shared underlying risk factor, such as trait impulsivity. We used bidirectional Mendelian Randomisation (MR) to test the gateway hypothesis.
\end{abstract}

Design:

Our main method was inverse-variance weighted (IVW) MR, with other methods included as sensitivity analyses (where consistent results across methods would raise confidence in our primary results). MR is a genetic instrumental variable approach used to support stronger causal inference in observational studies.

Setting:

European ancestry individuals.

Participants:

Genome-wide association summary data for smoking initiation, alcoholic drinks per week, cannabis use and dependence, cocaine and opioid dependence ( $N=1,749$ to $1,232,091)$.

Measurements:

Genetic variants for exposure.

Findings: 
medRxiv preprint doi: https://doi.org/10.1101/2021.01.12.21249649; this version posted August 5, 2021. The copyright holder for this preprint (which was not certified by peer review) is the author/funder, who has granted medRxiv a license to display the preprint in It is made available under a CC-BY 4.0 International license.

We found evidence of causal effects from smoking initiation to increased drinks per week (IVW: $\beta=0.06 ; 95 \% \mathrm{Cl}=0.03$ to $\left.0.09 ; p=9.44 \times 10^{-06}\right)$, cannabis use (IVW: $\mathrm{OR}=1.34 ; 95 \% \mathrm{Cl}=1.24$ to $1.44 ; \mathrm{p}=1.95 \times 10^{-14}$ ), and cannabis dependence (IVW: $\mathrm{OR}=1.68 ; 95 \% \mathrm{Cl}=1.12$ to 2.51 ; $p=0.01$ ). We also found evidence of an effect of cannabis use on increased likelihood of smoking initiation (IVW: $\mathrm{OR}=1.39 ; 95 \% \mathrm{Cl}=1.08$ to $1.80 ; \mathrm{p}=0.01$ ). We did not find evidence of an effect of drinks per week on other substance use outcomes, except weak evidence of an effect on cannabis use. We found weak evidence of an effect of opioid dependence on increased drinks per week (IVW: $\beta=0.002 ; 95 \% \mathrm{Cl}=0.0005$ to $0.003 ; p=8.61 \times 10^{-03}$ ).

\section{Conclusions:}

Smoking initiation may lead to increased alcohol consumption, cannabis use and dependence. Cannabis use may also lead to smoking initiation, and opioid dependence to alcohol consumption. However, given tobacco and alcohol use typically begin before other drug use, these results may reflect a shared risk factor, or a bidirectional effect for cannabis use. Further research should explore potentially shared risk factors.

Key words: Mendelian randomisation, substance use, smoking initiation, alcohol consumption, gateway hypothesis 
medRxiv preprint doi: https://doi.org/10.1101/2021.01.12.21249649; this version posted August 5, 2021. The copyright holder for this preprint (which was not certified by peer review) is the author/funder, who has granted medRxiv a license to display the preprint in It is made available under a CC-BY 4.0 International license.

\section{Introduction}

Illicit substance use and substance use disorders result in a substantial global burden on a range of health conditions $(1,2)$. Identifying causal risk factors in the development of problematic substance use is important for designing successful interventions and preventing subsequent health problems.

The gateway hypothesis, in its simplest form, is the theory that initial use of legal 'gateway' drugs, including tobacco and alcohol, may lead to illicit drug use, such as cannabis, cocaine and opioids (3-5). Previous studies have found associations between smoking initiation and use of alcohol (6), cannabis $(7,8)$, cocaine (9) and opioids (10). Studies also suggest alcohol as a possible gateway drug (11-14). Given that tobacco and alcohol consumption are likely to both occur initially during adolescence, and typically before other drug taking, it is important to investigate both as potential gateway drugs. Prospective studies also support the gateway hypothesis for these outcomes $(7,8,15-17)$, suggesting possible causal relationships. Substance use behaviours are moderately heritable ( $21 \%$ to $72 \%$ in twin studies) (18-22). Genetic correlations have also been found between different substance use phenotypes ( $r_{G} 0.35$ to 0.66$)(23-26)$.

Whilst these studies may support the gateway hypothesis, it is equally plausible that there are underlying shared risk factors, for example risk taking or impulsive behaviours. Previous studies have reported an association of ADHD with substance use outcomes $(27,28)$, and ADHD genetic risk with smoking initiation $(29,30)$, supporting impulsivity as a potential shared risk factor, although others - such as risk taking, or adverse childhood experiences could also lead to these outcomes. In terms of establishing whether the relationships between smoking and alcohol and other substance use are causal, there is some evidence 
medRxiv preprint doi: https://doi.org/10.1101/2021.01.12.21249649; this version posted August $5,2021$. The copyright holder for this preprint (which was not certified by peer review) is the author/funder, who has granted medRxiv a license to display the preprint in It is made available under a CC-BY 4.0 International license.

(e.g., from randomised controlled trials) that smoking cessation may result in reduced substance use or abstinence (31); supporting a possible causal effect of smoking on substance use outcomes.

Mendelian Randomisation (MR) is a well-established method for causal inference, based on instrumental variable (IV) analysis, which attempts to overcome issues of residual confounding and reverse causation (32-35). MR uses genetic variants, assigned randomly at conception, as IVs for an exposure to estimate the causal relationship with an outcome. In two-sample MR (36) the single nucleotide polymorphism (SNP)-exposure and SNP-outcome estimates are obtained from independent sample genome-wide association studies (GWAS) to estimate possible causal effects. Previous MR studies examining this relationship looked at cannabis use only, and used smaller GWAS sample sizes than in the current study. One study found weak evidence of a causal effect of smoking initiation on cannabis use (37), whilst the other found no evidence (38). Incorporating larger GWAS and a range of substance use outcomes may improve power to detect causal effects and provide better evidence as to whether these relationships are due to a gateway effect.

We applied this two-sample MR approach to investigate the possible causal effect between both smoking initiation and alcohol consumption (defined as drinks per week) and substance use outcomes of cannabis use and dependence, cocaine dependence and opioid dependence. We refer to these outcomes as illicit substance use, although we acknowledge that cannabis is not illegal in all jurisdictions. We also examined the association between smoking initiation and alcohol consumption. We used a bidirectional approach (Figure 1) to assess whether there is evidence supporting the gateway hypothesis (i.e., that smoking initiation/alcohol consumption can lead to use of other substances and dependence), or 
medRxiv preprint doi: https://doi.org/10.1101/2021.01.12.21249649; this version posted August 5, 2021. The copyright holder for this preprint (which was not certified by peer review) is the author/funder, who has granted medRxiv a license to display the preprint in It is made available under a CC-BY 4.0 International license.

whether there is evidence of a shared risk factor. Some pathways (e.g., from opioid use to smoking initiation) are unlikely, so analyses in this direction acted more as a sensitivity analysis, which could help identify a shared risk factor rather than a causal effect.

**Figure $1 * *$ 
medRxiv preprint doi: https://doi.org/10.1101/2021.01.12.21249649; this version posted August 5, 2021. The copyright holder for this preprint (which was not certified by peer review) is the author/funder, who has granted medRxiv a license to display the preprint in It is made available under a CC-BY 4.0 International license.

\section{Methods}

\section{Data sources}

We used GWAS summary statistics obtained from several consortia and other samples, the details of which are shown in Table 1, along with the variance explained by genome-wide significant SNPs and SNP heritabilities where these were reported. GWAS were conducted in samples of European ancestry. Sample overlap should be avoided or reduced, so as not to bias the estimates towards a more conservative effect estimate (39). Therefore, we used GWAS with certain samples excluded from the consortia (see Table 1).

**Table $1 * *$

\section{Smoking initiation}

The smoking initiation GWAS (23) identified 378 conditionally independent genome-wide significant SNPs associated with ever being a smoker i.e., where participants reported ever being a regular smoker in their life. See Supplementary Materials for further details. The total sample size was $1,232,091$ for the GSCAN consortium, however the sample size for the GWAS in each of our analyses varied to try and avoid sample overlap (see Table 1). Full genome-wide summary statistics were only publicly available without 23 andMe. We requested 23andMe summary statistics separately and meta-analysed them with the publicly available data to recreate the original full GWAS summary statistics. The metaanalysis was conducted using the genome-wide association meta-analysis (GWAMA) software (40).

Drinks per week 
medRxiv preprint doi: https://doi.org/10.1101/2021.01.12.21249649; this version posted August 5, 2021. The copyright holder for this preprint (which was not certified by peer review) is the author/funder, who has granted medRxiv a license to display the preprint in It is made available under a CC-BY 4.0 International license.

The drinks per week GWAS (23) identified 99 independent genome-wide significant SNPs associated with the average number of alcoholic drinks consumed per week. See Supplementary Materials for further details.

\section{Cannabis use}

The cannabis use GWAS (41) identified 8 independent genome-wide significant SNPs associated with ever using cannabis. See Supplementary Materials for further details.

\section{Cannabis dependence}

The cannabis dependence GWAS (42) did not identify any genome-wide significant SNPs associated with cannabis dependence. Cases were established based on meeting three or more criteria for Diagnostic and Statistical Manual of Mental Disorders, 4th edition (DSM-IV) cannabis dependence.

\section{Cocaine dependence}

The cocaine dependence GWAS (43) identified one genome-wide significant SNP associated with cocaine dependence. All participants were interviewed using the Semi-structured Assessment for Drug Dependence and Alcoholism (SSADA) and cocaine dependent cases were established based on responses according to the DSM-IV criteria and reflect lifetime cocaine dependence.

\section{Opioid dependence}

The opioid dependence GWAS (44) did not identify any genome-wide significant SNPS associated with opioid dependence. All participants were interviewed using the SSADA and 
medRxiv preprint doi: https://doi.org/10.1101/2021.01.12.21249649; this version posted August 5, 2021. The copyright holder for this preprint (which was not certified by peer review) is the author/funder, who has granted medRxiv a license to display the preprint in It is made available under a CC-BY 4.0 International license.

opioid dependent cases were established based on responses according to the DSM-IV criteria and reflect lifetime opioid dependence.

Units for all binary measures were in log odds ratios and for the continuous drinks per week measure were per SD increase in the number of drinks per week.

\section{Statistical analyses}

MR was used to assess whether relationships may be causal by using genetic variants as IV proxies for the exposures. Further details can be found in the supplementary materials. Two-sample MR was conducted in R (version 4.0.0) (45) using the TwoSampleMR package (version 0.5.3) $(46,47)$. Genome-wide significant SNPs were selected as instruments for the smoking initiation, alcohol and cannabis use exposures. However, where cocaine, opioid and cannabis dependence were the exposures there were either too few or no genome-wide significant SNPs, so we used a less stringent threshold of $1 \times 10^{-05}$.

Multiple MR methods were used to assess the causal effects of: i) the exposure of smoking initiation/alcohol consumption on illicit substance use outcomes, and ii) illicit substance use exposures on smoking initiation/alcohol consumption. These were inverse-variance weighted (IVW) (48), MR-Egger (49), weighted median (50), simple mode and weighted mode (51) MR methods. We were interested in the question of whether there is evidence of causal effects. We were concerned with the strength of evidence for an effect, as opposed to the effect estimate and considered whether the direction of effect was as predicted and the strength of statistical evidence against the null. To do this we interpreted the $p$-value as a continuous measure of statistical evidence (52) and considered whether our results were consistent across different MR approaches. The IVW approach was our main method, with 
medRxiv preprint doi: https://doi.org/10.1101/2021.01.12.21249649; this version posted August 5, 2021. The copyright holder for this preprint (which was not certified by peer review) is the author/funder, who has granted medRxiv a license to display the preprint in It is made available under a CC-BY 4.0 International license.

the others being sensitivity analyses which make different assumptions. We describe our findings in terms of lack of evidence, weak evidence, evidence, or strong evidence of an effect, accounting for all these factors. The sensitivity methods have less statistical power than the IVW approach; therefore we considered all results, and the consistency of the direction of effect observed across analyses. Inconsistent results for these sensitivity analyses may indicate that some MR assumptions are violated (e.g., pleiotropic pathways are operating). Specifically, the IVW method constrains the intercept to be zero and assumes all SNPs are valid instruments with no horizontal pleiotropy. Horizontal pleiotropy can be problematic as MR assumptions may be violated if the SNPs affect the outcome via a different pathway. Therefore, we included additional tests which can detect whether horizontal pleiotropy may be present. For example, we included results for the Cochran's test of heterogeneity, which assesses whether there is heterogeneity in the SNPexposureSNP outcome associations for each SNP included in the instrument. If there is evidence of heterogeneity this may indicate possible horizontal pleiotropy.

The MR-Egger method tests whether there is overall directional pleiotropy by not constraining the intercept, where a non-zero intercept indicates directional horizontal pleiotropy. We also used the Rucker's Q-test to assess heterogeneity in the MR-Egger estimates for individual SNPs, similar to the Cochran's test. The weighted median method provides an estimate under the assumption that at least $50 \%$ of the SNPs are valid instruments (i.e., satisfy the IV assumptions). Finally, the mode-based approaches provide an estimate for the largest cluster of similar SNPs, where the SNPs not in that cluster could be invalid, with the weighted method taking into account the largest weights of SNPs. 
medRxiv preprint doi: https://doi.org/10.1101/2021.01.12.21249649; this version posted August 5, 2021. The copyright holder for this preprint (which was not certified by peer review) is the author/funder, who has granted medRxiv a license to display the preprint in It is made available under a CC-BY 4.0 International license.

Additionally, we also estimated effects for single SNP and leave-one-out analyses and plotted these results, where there was evidence for a causal effect.

We also estimated the mean F-statistic, unweighted and weighted I-squared values for each of the analyses (53). The F-statistic represents instrument strength, where a value under 10 may indicate a weak instrument (53). The I-squared value falls between zero and one and indicates the amount of bias in the 'NO Measurement Error' (NOME) assumption in the MREgger estimate. If bias was apparent, we ran run simulation extrapolation (SIMEX) corrections and present these in place of the MR-Egger results, or if the bias was too large neither were presented (see supplementary materials for further details).

Finally, we conducted multivariable MR (MVMR) to investigate whether the causal effect of smoking initiation was independent of that for the drinks per week exposure for any illicit substance use outcomes where both exposures were associated with the outcome. MVMR is an extension of MR that estimates the causal effect of multiple exposures on an outcome and assesses whether each exposure is independent of the others (54). Please note that our analyses were not pre-registered and therefore our results should be considered exploratory. 
medRxiv preprint doi: https://doi.org/10.1101/2021.01.12.21249649; this version posted August 5, 2021. The copyright holder for this preprint (which was not certified by peer review) is the author/funder, who has granted medRxiv a license to display the preprint in It is made available under a CC-BY 4.0 International license.

\section{Results}

Evidence of causal effects of smoking initiation on illicit substance use outcomes

Our two-sample MR results (Table S2 and Figure 2) indicated there was evidence for a causal effect of smoking initiation on increased drinks per week (IVW: $\beta=0.06 ; 95 \% \mathrm{Cl} 0.03$ to 0.09 ; $p$-value $\left.=9.44 \times 10^{-06}\right)$. The I-squared values (Table S1) suggest the MR Egger method was unsuitable; therefore, results are not presented for this. Results were in a consistent direction with evidence of a causal effect across the different MR analyses (see also Figure S1). We observed evidence of heterogeneity in results for the IVW method (see also Figure S2), but this was not necessarily indicative of horizontal pleiotropy (see also Figure S3). Leave-one-out analyses did not reveal that any single SNP was driving the association (Figure S4).

We also found evidence of a causal effect of smoking initiation on cannabis use (IVW: $\mathrm{OR}=1.34 ; 95 \% \mathrm{Cl}=1.24$ to $1.44 ; \mathrm{p}$-value $\left.=1.95 \times 10^{-14}\right)$. Results were in a consistent direction across MR analyses (see also Figure S5), although evidence for this was only found additionally for the weighted median method. There was evidence of heterogeneity with both the IVW and MR Egger methods (see also Figure S6) but not horizontal pleiotropy (see also Figure S7). Leave-one-out analyses did not reveal that any single SNP was driving the association (Figure S8).

We found evidence of a causal effect of smoking initiation on cannabis dependence (IVW: $\mathrm{OR}=1.68 ; 95 \% \mathrm{Cl} 1.12$ to $2.51 ; \mathrm{p}$-value=0.01). Results were in a consistent direction for the SIMEX adjusted MR Egger and weighted median methods (Table S1), although evidence for these was weak (see also Figure S9). There was no evidence of heterogeneity or horizontal 
medRxiv preprint doi: https://doi.org/10.1101/2021.01.12.21249649; this version posted August 5, 2021. The copyright holder for this preprint (which was not certified by peer review) is the author/funder, who has granted medRxiv a license to display the preprint in It is made available under a CC-BY 4.0 International license.

pleiotropy (also see Figures S10 and S11). Leave-one-out analyses did not reveal that any single SNP was driving the association (Figure S12).

Finally, we did not find evidence of a causal effect of smoking initiation on cocaine dependence (IVW: OR=1.21; $95 \% \mathrm{Cl} 0.58$ to 2.53 ; $p$-value=0.60) or opioid dependence (IVW: $\mathrm{OR}=1.41 ; 95 \% \mathrm{Cl} 0.62$ to $3.20 ; \mathrm{p}$-value=0.41) with any of the MR analyses, except for weak evidence for the SIMEX adjusted (Table S1) MR-Egger for cocaine dependence. There was no evidence of heterogeneity or horizontal pleiotropy for cocaine or opioid dependence.

**Figure $2 * *$

Causal effects of illicit substance use exposures on smoking initiation

For the direction of illicit substance use to smoking initiation (Table S3 and Figure 3) we found evidence of a causal effect of cannabis use on smoking initiation (IVW: OR=1.39; 95\% $\mathrm{Cl}=1.08$ to 1.80; $\mathrm{p}$-value=0.01) for all MR analyses except MR Egger. Results were in a consistent direction across MR analyses (see also Figure S13). We observed evidence of heterogeneity in these results for the IVW and MR Egger methods (see also Figure S14), but not horizontal pleiotropy (see also Figure S15). Leave-one-out analyses did not reveal that any single SNP was driving the association (Figure S16).

We did not find any evidence of a causal effect of drinks per week, (IVW: OR=1.26; 95\% $\mathrm{Cl}=0.92$ to $1.72 ; \mathrm{p}$-value $=0.15$ ), cannabis dependence (IVW: $\mathrm{OR}=1.00 ; 95 \% \mathrm{Cl}=0.99$ to 1.01 ; $\mathrm{p}$-value=0.60), cocaine dependence (IVW: $\mathrm{OR}=1.00 ; 95 \% \mathrm{Cl}=1.00$ to $1.00 ; \mathrm{p}$-value $=0.42$ ) or opioid dependence (IVW: OR=1.00; 95\% $\mathrm{Cl}=0.99$ to $1.01 ; \mathrm{p}$-value=0.80) on smoking initiation, for any of the MR analyses. 
medRxiv preprint doi: https://doi.org/10.1101/2021.01.12.21249649; this version posted August 5, 2021. The copyright holder for this preprint (which was not certified by peer review) is the author/funder, who has granted medRxiv a license to display the preprint in It is made available under a CC-BY 4.0 International license.

\section{**Figure $3 * *$}

\section{Causal effects of drinks per week on illicit substance use outcomes}

When examining whether there was evidence for causal effects of alcohol consumption (drinks per week) on the illicit substance use phenotypes (Table S4 and Figure 4) we did not find any evidence for the IVW approach for cannabis use (IVW: OR=0.55; 95\% $\mathrm{Cl}=0.16$ to 1.93; $p$-value=0.35), although there was some evidence of a causal effect with the other MR analyses. We did not find evidence of a causal effect on cannabis dependence (IVW:

$\mathrm{OR}=2.73 ; 95 \% \mathrm{Cl}=0.62$ to $11.95 ; \mathrm{p}$-value=0.18), cocaine dependence (IVW: OR=0.50; 95\% $\mathrm{Cl}=0.09$ to $2.79 ; \mathrm{p}$-value $=0.43$ ) or opioid dependence (IVW: $\mathrm{OR}=0.38 ; 95 \% \mathrm{Cl}=0.06$ to $2.41 ; \mathrm{p}$ value $=0.30)$.

\section{**Figure $4 * *$}

\section{Causal effects of illicit substance use exposures on drinks per week}

For the reverse direction (Table S5 and Figure 5) we did not find evidence of a causal effect of cannabis use (IVW: $\beta=0.03 ; 95 \% \mathrm{Cl}=-0.009$ to $0.07 ; p$-value=0.14), cannabis dependence (IVW: $\beta=-0.0003 ; 95 \% \mathrm{Cl}=-0.003$ to $0.002 ; p$-value $=0.80$ ) or cocaine dependence (IVW: $\beta=0.0007 ; 95 \% \mathrm{Cl}=-0.00007$ to $0.001 ; p$-value $=0.08$ ) on drinks per week.

There was weak evidence to suggest a causal effect of opioid dependence on drinks per week (IVW: $\beta=0.002 ; 95 \% \mathrm{Cl}=0.0005$ to $0.003 ; p$-value $=8.61 \times 10^{-03}$ ), although the effect size was very small, and this was not found for any other MR analyses (see also Figure S17). There was no evidence of heterogeneity (see also Figure S18) or horizontal pleiotropy 
medRxiv preprint doi: https://doi.org/10.1101/2021.01.12.21249649; this version posted August 5, 2021. The copyright holder for this preprint (which was not certified by peer review) is the author/funder, who has granted medRxiv a license to display the preprint in It is made available under a CC-BY 4.0 International license.

(Figure S19). Leave-one-out analyses did not reveal that any single SNP was driving the association (Figure S20).

$* *$ Figure $5^{* *}$

Multivariable Mendelian Randomisation analysis for cannabis use

We conducted MVMR analysis for cannabis use only due to evidence of a causal effect of smoking initiation on cannabis use and weak evidence of a causal effect of drinks per week on cannabis use. We found evidence of a direct effect of smoking initiation, independent of drinks per week on cannabis use $\left(\mathrm{OR}=1.35 ; 95 \% \mathrm{Cl}=1.25\right.$ to $1.46 ; \mathrm{p}$-value $\left.=3.67 \times 10^{-12}\right)$. This result was similar to that from the two-sample MR model. However, there was no evidence of a direct effect of drinks per week on cannabis use $(\mathrm{OR}=0.71 ; 95 \% \mathrm{Cl}=0.29$ to $1.76 ; \mathrm{p}$ value $=0.47$ ) . 
medRxiv preprint doi: https://doi.org/10.1101/2021.01.12.21249649; this version posted August $5,2021$. The copyright holder for this preprint (which was not certified by peer review) is the author/funder, who has granted medRxiv a license to display the preprint in It is made available under a CC-BY 4.0 International license.

\section{Discussion}

We examined whether there was evidence for causal effects of smoking initiation and alcohol consumption on cannabis use and dependence on cannabis, cocaine and opioids, which may support the 'gateway' hypothesis. We also examined the reverse direction, where evidence of an association, particularly in both directions may be indicative of an underlying common risk factor.

Our main findings were those for cannabis use and dependence, which suggest that ever smoking may act as a gateway to subsequent cannabis use and perhaps even dependence, although evidence was weaker for the latter. This supports previous observational studies demonstrating an association between these phenotypes $(7,8,55)$ and is in line with previous findings suggesting tobacco is a gateway drug to other more problematic substance use $(5,6,8,10)$. Our MR analyses support stronger causal inference, although further triangulation with other study designs would strengthen this. Previous literature also suggests that alcohol consumption may be causally associated with cannabis use; however, our MVMR results suggest no evidence for independent effects of alcohol consumption, only evidence for a causal effect of smoking initiation on cannabis use.

We also found evidence for a potential causal pathway from cannabis use to smoking initiation. It has been previously suggested that cannabis use may act as gateway to tobacco use, possibly due to the form in which cannabis is used, i.e., if smoked with tobacco (56). However, our finding of potential causal pathways between cannabis use and smoking initiation in both directions may suggest this association is due to an underlying common risk factor, as opposed to either being a gateway drug. We found that all the SNPs used in the cannabis use instrument, except one, are in LD with genome-wide significant SNPs in the 
medRxiv preprint doi: https://doi.org/10.1101/2021.01.12.21249649; this version posted August 5, 2021. The copyright holder for this preprint (which was not certified by peer review) is the author/funder, who has granted medRxiv a license to display the preprint in It is made available under a CC-BY 4.0 International license.

smoking initiation GWAS $\left(r^{2}>0.27,250 \mathrm{~kb}\right.$ window for 3 SNPs). As this the genetic instruments may be overlapping, this does not help us disentangle the reason behind this relationship.

There are several potential reasons for our results: 1) a causal effect of smoking initiation on cannabis use, 2) a causal effect of cannabis use on smoking initiation, 3) a bidirectional effect, 4) an underlying shared risk factor, 5) horizontal pleiotropy (although our sensitivity analyses suggested this was not biasing results), and 6) confounding due to LD. Without further understanding of the biological function of these genetic variants it is difficult to conclude which of these explanations (which are not mutually exclusive) could be true here and this has been discussed previously in relation to mental health behavioural risk factors $(57,58)$. Previous studies have suggested that impulsive or risk-taking behaviours may be associated with smoking initiation and substance use (59-61). Additionally, cannabis use may capture underlying risk-taking behaviours more than the dependence measures and this may be why we see a more consistent association with this measure. Further research is needed to establish whether there could be an underlying common cause, and if this might be related to risk-taking behaviours. Other potential shared risk factors should also be considered, and these may be genetic or environmental in origin and may vary between different illicit substance use phenotypes. In addition, it may be the case that smoking initiation, for example, only acts as a gateway to other substances in the presence of mediators such as stressful life events or adverse circumstances. Therefore, the mechanisms behind these associations need to be examined further, and the possibility of a bidirectional relationship should also be considered. 
medRxiv preprint doi: https://doi.org/10.1101/2021.01.12.21249649; this version posted August $5,2021$. The copyright holder for this preprint (which was not certified by peer review) is the author/funder, who has granted medRxiv a license to display the preprint in It is made available under a CC-BY 4.0 International license.

We found a potential causal effect of smoking initiation on increased drinks per week, but did not find an association in the reverse direction. It is plausible that an underlying risktaking behaviour may affect alcohol consumption via smoking. However, a biological mechanism behind this association should also be considered and studied further. Finally, we did see weak evidence of a causal effect of opioid dependence on increased drinks per week; however, due to the low power for the opioid dependence GWAS and the small effect size we would interpret this with caution. Opioid dependence (compared with ever use) is less likely explained by underlying risk-taking behaviour. Therefore, research into alternative shared risk factors is warranted. It may be the case that opioid dependence does have a causal effect on increased alcohol use, and this also warrants further investigation.

\section{Limitations}

Our study is the first, to our knowledge, to examine whether causal pathways may exist between smoking initiation/alcohol consumption and various illicit substance use phenotypes, using an MR approach. However, there are several limitations to note, for example some of our analyses may be limited in their power to detect a causal effect. This is particularly the case where the dependence measures were the exposures, as the GWAS discovery samples were much smaller than those for drinks per week, cannabis use and smoking initiation. Additionally, we used a less stringent $p$-value threshold of $1 \times 10^{-05}$ due to a low number of genome-wide significant SNPs. Therefore, these instruments may be less robustly associated with the exposure, and pleiotropy could be introduced. For our results with the dependence variables as exposures, the Cls were very narrow which could be a result of the relaxed p-value thresholds used. However, the absence of evidence here does not mean we can exclude the possibility of an effect for this relationship. Furthermore, the 
medRxiv preprint doi: https://doi.org/10.1101/2021.01.12.21249649; this version posted August 5, 2021. The copyright holder for this preprint (which was not certified by peer review) is the author/funder, who has granted medRxiv a license to display the preprint in It is made available under a CC-BY 4.0 International license .

lower number of SNPs used for the dependence exposures may mean the instruments are weak, which may be particularly problematic for MR-Egger. For our finding of an effect of opioid dependence on drinks per week, additional caution should be taken when interpreting this result as the opioid dependence exposure is a dichotomised variable for an underlying latent risk factor. Thus, the estimate here is less interpretable than for our other results and instead focus should be on the direction and evidence of an effect as opposed to the effect size. Therefore, our dependence results should be interpreted with caution revisited once larger GWAS become available.

We also found some evidence of heterogeneity and horizontal pleiotropy for different analyses meaning that these results should be interpreted in light of this, as some of the SNPs used may be associated with the outcome other than via the exposure. However, the additional MR analyses, which account for this, were generally in the same direction as our main results, although we were unable to formally test for directional pleiotropy in some cases where the I-squared estimate was low. In cases where the IVW shows evidence for a causal effect, but results are inconsistent across the sensitivity analyses, this may be indicative of pleiotropy. However, inconsistent effects across sensitivity analyses and no evidence from the IVW is more likely to reflect a lack of evidence for an effect.

Another consideration is that the MR instruments used may not be valid for smoking as they may be picking up risk-taking behaviours more than smoking itself (62). Therefore, it would be useful to examine this further with other smoking related phenotypes such as smoking heaviness. Additionally, whilst we tried to avoid sample overlap, there was still some for the cannabis use GWAS ( $17 \%$ of the sample was also present in the GWAS for smoking initiation 
medRxiv preprint doi: https://doi.org/10.1101/2021.01.12.21249649; this version posted August 5, 2021. The copyright holder for this preprint (which was not certified by peer review) is the author/funder, who has granted medRxiv a license to display the preprint in It is made available under a CC-BY 4.0 International license.

and drinks per week). Sample overlap could bias estimates towards a more conservative effect estimate (39), which should be considered when interpreting our results.

The MR analysis itself is subject to several limitations (33). For example, the GWAS used for MR may suffer from 'Winner's curse', where the SNP-exposure estimates may be overestimated, due to selecting SNPs with the smallest $p$-values and biasing the MR estimate towards the null. Thus, interpreting the direction of effect as opposed to the effect size itself is more valid here. The effect estimate may also be biased by trait heterogeneity, for example, different aspects of substance use behaviours may be associated with the same genetic variants and therefore it is difficult to get a precise estimate for a single aspect of any substance use behaviour.

Finally, our results should be considered in the context of the multiple potential causal pathways that we have investigated.

\section{Conclusion}

Whilst our findings support the gateway hypothesis to some extent, they also point to a potential underlying common risk factor and with better powered GWAS or those with more precise instruments and additional research we may be able to interrogate this further. Triangulating our results with other approaches would help answer this question $(63,64)$. By doing so we may be able to identify risk factors to substance use which could ultimately help with intervention design. 
medRxiv preprint doi: https://doi.org/10.1101/2021.01.12.21249649; this version posted August 5, 2021. The copyright holder for this preprint (which was not certified by peer review) is the author/funder, who has granted medRxiv a license to display the preprint in It is made available under a CC-BY 4.0 International license.

\section{Acknowledgements}

We thank all the contributors to the consortia we have used GWAS results from in our analyses. We would like to thank the research participants and employees of 23andMe for making this work possible.

\section{Funding}

This work was supported in part by Public Health England, the UK Medical Research Council Integrative Epidemiology Unit at the University of Bristol (Grant ref: MC_UU_00011/7), and the National Institute for Health Research (NIHR) Biomedical Research Centre at the University Hospitals Bristol National Health Service Foundation Trust and the University of Bristol. The views expressed in this publication are those of the authors and not necessarily those of the National Health Service, the National Institute for Health Research or the Department of Health. Robyn Wootton was supported by a postdoctoral fellowship from the South-Eastern Regional Health Authority (2020024). 
medRxiv preprint doi: https://doi.org/10.1101/2021.01.12.21249649; this version posted August 5, 2021. The copyright holder for this preprint (which was not certified by peer review) is the author/funder, who has granted medRxiv a license to display the preprint in It is made available under a CC-BY 4.0 International license.

\section{References}

1. Schulte MT, Hser YI. Substance use and associated health conditions throughout the lifespan. Vol. 35, Public Health Reviews. NIH Public Access; 2014.

2. Degenhardt L, Charlson F, Ferrari A, Santomauro D, Erskine H, Mantilla-Herrara A, et al. The global burden of disease attributable to alcohol and drug use in 195 countries and territories, 1990-2016: a systematic analysis for the Global Burden of Disease Study 2016. The Lancet Psychiatry. 2018 Dec 1;5(12):987-1012.

3. Kleinig J. Ready for Retirement: The Gateway Drug Hypothesis. Subst Use Misuse. 2015;50(8-9):971-5.

4. Bell K, Keane H. All gates lead to smoking: The "gateway theory", e-cigarettes and the remaking of nicotine. Soc Sci Med. 2014 Oct 1;119:45-52.

5. Kandel DB, Yamaguchi K, Chen K. Stages of Progression in Drug Involvement from Adolescence to Adulthood: Further Evidence for the Gateway Theory. J Stud Alcohol. 1992;

6. Chen X, Unger JB, Palmer P, Weiner MD, Johnson CA, Wong MM, et al. Prior cigarette smoking initiation predicting current alcohol use: Evidence for a gateway drug effect among California adolescents from eleven ethnic groups. Addict Behav. 2002 Sep 1;27(5):799-817.

7. Haug S, Núñez CL, Becker J, Gmel G, Schaub MP. Predictors of onset of cannabis and other drug use in male young adults: Results from a longitudinal study. BMC Public Health. 2014 Dec 22;14(1):1202. 
medRxiv preprint doi: https://doi.org/10.1101/2021.01.12.21249649; this version posted August 5, 2021. The copyright holder for this preprint (which was not certified by peer review) is the author/funder, who has granted medRxiv a license to display the preprint in It is made available under a CC-BY 4.0 International license.

8. Korhonen T, van Leeuwen AP, Reijneveld SA, Ormel J, Verhulst FC, Huizink AC.

Externalizing Behavior Problems and Cigarette Smoking as Predictors of Cannabis Use:

The TRAILS Study. J Am Acad Child Adolesc Psychiatry. 2010;49(1):61-9.

9. Levine A, Huang YY, Drisaldi B, Griffin EA, Pollak DD, Xu S, et al. Molecular mechanism for a gateway drug: Epigenetic changes initiated by nicotine prime gene expression by cocaine. Sci Transl Med. 2011;3(107).

10. Woodcock EA, Lundahl LH, Stoltman JJK, Greenwald MK. Progression to regular heroin use: Examination of patterns, predictors, and consequences. Addict Behav. 2015 Jun 1;45:287-93.

11. Kirby T, Barry AE. Alcohol as a Gateway Drug: A Study of US 12th Graders. J Sch Health. 2012;82(8):371-9.

12. Willner P. A view through the gateway: Expectancies as a possible pathway from alcohol to cannabis. Addiction. 2001;96(5):691-703.

13. Barry AE, King J, Sears C, Harville C, Bondoc I, Joseph K. Prioritizing Alcohol Prevention: Establishing Alcohol as the Gateway Drug and Linking Age of First Drink With Illicit Drug Use. J Sch Health. 2016 Jan 1;86(1):31-8.

14. Miller ML, Hurd YL. Testing the Gateway Hypothesis. Neuropsychopharmacology. 2017;42(5):985-6.

15. Ruggles K V., Fang Y, Tate J, Mentor SM, Bryant KJ, Fiellin DA, et al. What are the Patterns Between Depression, Smoking, Unhealthy Alcohol Use, and Other Substance Use Among Individuals Receiving Medical Care? A Longitudinal Study of 5479 
medRxiv preprint doi: https://doi.org/10.1101/2021.01.12.21249649; this version posted August 5, 2021. The copyright holder for this preprint (which was not certified by peer review) is the author/funder, who has granted medRxiv a license to display the preprint in It is made available under a CC-BY 4.0 International license.

Participants. AIDS Behav. 2017 Jul 30;21(7):2014-22.

16. Strong C, Juon HS, Ensminger ME. Effect of adolescent cigarette smoking on adulthood substance use and abuse: The mediating role of educational attainment. Subst Use Misuse. 2016;51(2):141-54.

17. Thrul J, Rabinowitz JA, Reboussin BA, Maher BS, lalongo NS. Adolescent cannabis and tobacco use are associated with opioid use in young adulthood-12-year longitudinal study in an urban cohort. Addiction. 2021 Mar 21;116(3):643-50.

18. Verweij KJH, Zietsch BP, Lynskey MT, Medland SE, Neale MC, Martin NG, et al. Genetic and environmental influences on cannabis use initiation and problematic use: A meta-analysis of twin studies. Addiction. 2010 Mar;105(3):417-30.

19. Goldman D, Oroszi G, Ducci F. The genetics of addictions: uncovering the genes. Nat Rev Genet. 2005 Jul;6(7):521-32.

20. Mistry C, Bawor M, Desai D, Marsh D, Samaan Z. Genetics of Opioid Dependence: A Review of the Genetic Contribution to Opioid Dependence. Curr Psychiatry Rev. 2014 May;10(2):156-67.

21. Vink JM, Willemsen G, Boomsma DI. Heritability of smoking initiation and nicotine dependence. Behav Genet. 2005;35(4):397-406.

22. Virtanen S, Kaprio J, Viken R, Rose RJ, Latvala A. Birth cohort effects on the quantity and heritability of alcohol consumption in adulthood: a Finnish longitudinal twin study. Addiction. 2019 May 7;114(5):836-46.

23. Liu M, Jiang Y, Wedow R, Li Y, Brazel DM, Chen F, et al. Association studies of up to 
medRxiv preprint doi: https://doi.org/10.1101/2021.01.12.21249649; this version posted August 5, 2021. The copyright holder for this preprint (which was not certified by peer review) is the author/funder, who has granted medRxiv a license to display the preprint in It is made available under a CC-BY 4.0 International license.

1.2 million individuals yield new insights into the genetic etiology of tobacco and alcohol use. Vol. 51, Nature Genetics. Nature Publishing Group; 2019. p. 237-44.

24. Johnson EC, Demontis D, Thorgeirsson TE, Walters RK, Polimanti R, Hatoum AS, et al. A large-scale genome-wide association study meta-analysis of cannabis use disorder. The lancet Psychiatry. 2020 Dec 1;7(12):1032-45.

25. Cabana-Domínguez J, Shivalikanjli A, Fernàndez-Castillo N, Cormand B. Genome-wide association meta-analysis of cocaine dependence: Shared genetics with comorbid conditions. Prog Neuro-Psychopharmacology Biol Psychiatry. 2019 Aug 30;94:109667.

26. Zhou H, Rentsch CT, Cheng Z, Kember RL, Nunez YZ, Sherva RM, et al. Association of OPRM1 Functional Coding Variant with Opioid Use Disorder: A Genome-Wide Association Study. JAMA Psychiatry. 2020 Oct 1;77(10):1072-80.

27. Lee SS, Humphreys KL, Flory K, Liu R, Glass K. Prospective association of childhood attention-deficit/hyperactivity disorder (ADHD) and substance use and abuse/dependence: A meta-analytic review. Clin Psychol Rev. 2011 Apr 1;31(3):32841.

28. Zulauf CA, Sprich SE, Safren SA, Wilens TE. The complicated relationship between attention deficit/hyperactivity disorder and substance use disorders topical collection on child and adolescent disorders. Curr Psychiatry Rep. 2014;16(3):436.

29. Treur JL, Demontis D, Smith GD, Sallis H, Richardson TG, Wiers RW, et al. Investigating causality between liability to ADHD and substance use, and liability to substance use and ADHD risk, using Mendelian randomization. Addict Biol. 2019 Nov 16; 
medRxiv preprint doi: https://doi.org/10.1101/2021.01.12.21249649; this version posted August 5, 2021. The copyright holder for this preprint (which was not certified by peer review) is the author/funder, who has granted medRxiv a license to display the preprint in It is made available under a CC-BY 4.0 International license.

30. Biederman J, Monuteaux MC, Mick E, Wilens TE, Fontanella JA, Poetzl KM, et al. Is cigarette smoking a gateway to alcohol and illicit drug use disorders? A study of youths with and without attention deficit hyperactivity disorder. Biol Psychiatry. 2006 Feb 1;59(3):258-64.

31. McKelvey K, Thrul J, Ramo D. Impact of quitting smoking and smoking cessation treatment on substance use outcomes: An updated and narrative review. Addict Behav. 2017;65:161-70.

32. Davey Smith G, Ebrahim S. "Mendelian randomization": Can genetic epidemiology contribute to understanding environmental determinants of disease? Vol. 32, International Journal of Epidemiology. Oxford Academic; 2003. p. 1-22.

33. Haycock PC, Burgess S, Wade KH, Bowden J, Relton C, Davey Smith G. Best (but oftforgotten) practices: The design, analysis, and interpretation of Mendelian randomization studies. Am J Clin Nutr. 2016;103(4):965-78.

34. Lawlor DA, Harbord RM, Sterne JAC, Timpson N, Davey Smith G. Mendelian randomization: Using genes as instruments for making causal inferences in epidemiology. Stat Med. 2008;27(8):1133-63.

35. Davey Smith G, Hemani G. Mendelian randomization: genetic anchors for causal inference in epidemiological studies. Hum Mol Genet. 2014;23(R1):R89-98.

36. Burgess S, Scott RA, Timpson NJ, Davey Smith G, Thompson SG. Using published data in Mendelian randomization: A blueprint for efficient identification of causal risk factors. Eur J Epidemiol. 2015 Jul 15;30(7):543-52. 
medRxiv preprint doi: https://doi.org/10.1101/2021.01.12.21249649; this version posted August 5, 2021. The copyright holder for this preprint (which was not certified by peer review) is the author/funder, who has granted medRxiv a license to display the preprint in It is made available under a CC-BY 4.0 International license .

37. Verweij KJH, Treur JL, Vink JM. Investigating causal associations between use of nicotine, alcohol, caffeine and cannabis: a two-sample bidirectional Mendelian randomization study. Addiction. 2018 Jul 1;113(7):1333-8.

38. Chang LH, Ong JS, An J, Verweij KJH, Vink JM, Pasman J, et al. Investigating the genetic and causal relationship between initiation or use of alcohol, caffeine, cannabis and nicotine. Drug Alcohol Depend. 2020;210(January):107966.

39. Burgess S, Davies NM, Thompson SG. Bias due to participant overlap in two-sample Mendelian randomization. Genet Epidemiol. 2016 Nov 1;40(7):597-608.

40. Mägi R, Morris AP. GWAMA: Software for genome-wide association meta-analysis. BMC Bioinformatics. 2010 May;11(1):288.

41. Pasman JA, Verweij KJH, Gerring Z, Stringer S, Sanchez-Roige S, Treur JL, et al. GWAS of lifetime cannabis use reveals new risk loci, genetic overlap with psychiatric traits, and a causal influence of schizophrenia. Nat Neurosci. 2018 Sep 27;21(9):1161-70.

42. Agrawal A, Chou YL, Carey CE, Baranger DAA, Zhang B, Sherva R, et al. Genome-wide association study identifies a novel locus for cannabis dependence. Mol Psychiatry. 2018 May 7;23(5):1293-302.

43. Gelernter J, Sherva R, Koesterer R, Almasy L, Zhao H, Kranzler HR, et al. Genome-wide association study of cocaine dependence and related traits: FAM53B identified as a risk gene. Mol Psychiatry. 2014 Jun 20;19(6):717-23.

44. Gelernter J, Kranzler HR, Sherva R, Koesterer R, Almasy L, Zhao H, et al. Genome-wide association study of opioid dependence: Multiple associations mapped to calcium and 
medRxiv preprint doi: https://doi.org/10.1101/2021.01.12.21249649; this version posted August 5, 2021. The copyright holder for this preprint (which was not certified by peer review) is the author/funder, who has granted medRxiv a license to display the preprint in It is made available under a CC-BY 4.0 International license.

potassium pathways. Biol Psychiatry. 2014 Jul 1;76(1):66-74.

45. R Core Team. R: A language and environment for statistical computing. R Foundation for Statistical Computing, Vienna, Austria; 2016.

46. Hemani G, Tilling K, Davey Smith G. Orienting the causal relationship between imprecisely measured traits using GWAS summary data. Li J, editor. PLOS Genet. 2017 Nov 17;13(11):e1007081.

47. Hemani G, Zheng J, Wade KH, Laurin C, Elsworth B, Burgess S, et al. MR-Base: a platform for systematic causal inference across the phenome using billions of genetic associations. bioRxiv. 2016;78972.

48. Burgess S, Butterworth A, Thompson SG. Mendelian randomization analysis with multiple genetic variants using summarized data. Genet Epidemiol. 2013 Nov;37(7):658-65.

49. Bowden J, Davey Smith G, Burgess S. Mendelian randomization with invalid instruments: Effect estimation and bias detection through Egger regression. Int J Epidemiol. 2015;44(2):512-25.

50. Bowden J, Davey Smith G, Haycock PC, Burgess S. Consistent Estimation in Mendelian Randomization with Some Invalid Instruments Using a Weighted Median Estimator. Genet Epidemiol. 2016 May;40(4):304-14.

51. Hartwig FP, Davey Smith G, Bowden J. Robust inference in summary data Mendelian randomization via the zero modal pleiotropy assumption. Int J Epidemiol. $2017 \mathrm{Jul}$;

52. Sterne JA, Davey Smith G. Sifting the evidence-what's wrong with significance tests? 
medRxiv preprint doi: https://doi.org/10.1101/2021.01.12.21249649; this version posted August 5, 2021. The copyright holder for this preprint (which was not certified by peer review) is the author/funder, who has granted medRxiv a license to display the preprint in It is made available under a CC-BY 4.0 International license.

BMJ. 2001 Jan 27;322(7280):226-31.

53. Bowden J, Fabiola Del Greco M, Minelli C, Smith GD, Sheehan NA, Thompson JR. Assessing the suitability of summary data for two-sample mendelian randomization analyses using MR-Egger regression: The role of the I 2 statistic. Int J Epidemiol. 2016 Sep 11;45(6):1961-74.

54. Sanderson E, Davey Smith G, Windmeijer F, Bowden J. An examination of multivariable Mendelian randomization in the single-sample and two-sample summary data settings. Int J Epidemiol. 2019 Jun 1;48(3):713-27.

55. Hindocha C, Shaban NDC, Freeman TP, Das RK, Gale G, Schafer G, et al. Associations between cigarette smoking and cannabis dependence: A longitudinal study of young cannabis users in the United Kingdom. Drug Alcohol Depend. 2015 Mar 1;148:165-71.

56. Becker J, Schaub MP, Gmel G, Haug S. Cannabis use and other predictors of the onset of daily cigarette use in young men: What matters most? Results from a longitudinal study Health behavior, health promotion and society. BMC Public Health. 2015 Dec 2;15(1):843.

57. Jones HJ, Martin D, Lewis SJ, Davey Smith G, O’Donovan MC, Owen MJ, et al. A Mendelian randomization study of the causal association between anxiety phenotypes and schizophrenia. Am J Med Genet Part B Neuropsychiatr Genet. 2020 Sep 24;183(6):360-9.

58. Wootton RE, Jones HJ, Sallis HM. Mendelian randomisation for psychiatry: how does it work, and what can it tell us? Mol Psychiatry. 2021 Jun 4;1-5. 
medRxiv preprint doi: https://doi.org/10.1101/2021.01.12.21249649; this version posted August 5, 2021. The copyright holder for this preprint (which was not certified by peer review) is the author/funder, who has granted medRxiv a license to display the preprint in It is made available under a CC-BY 4.0 International license.

59. Gerard Moeller F, Dougherty DM. Impulsivity and substance abuse: What is the connection? Addict Disord their Treat. 2002;1(1):3-10.

60. Feldstein SW, Miller WR. Substance use and risk-taking among adolescents. J Ment Heal. 2006;15(6):633-43.

61. Bloom EL, Matsko S V., Cimino CR. The relationship between cigarette smoking and impulsivity: A review of personality, behavioral, and neurobiological assessment. Addict Res Theory. 2014;22(5):386-97.

62. Khouja JN, Wootton RE, Taylor AE, Smith GD, Munafò MR. Association of genetic liability to smoking initiation with e-cigarette use in young adults. medRxiv. 2020 Jun $12 ; 2020.06 .10 .20127464$.

63. Lawlor DA, Tilling K, Smith GD. Triangulation in aetiological epidemiology. Int J Epidemiol. 2017 Jan 20;45(6):1866-86.

64. Munafò MR, Davey Smith G. Robust research needs many lines of evidence. Nature. $2018 \operatorname{Jan} 23 ; 553(7689): 399-401$. 
medRxiv preprint doi: https://doi.org/10.1101/2021.01.12.21249649; this version posted August 5, 2021. The copyright holder for this preprint (which was not certified by peer review) is the author/funder, who has granted medRxiv a license to display the preprint in perpetuity.

It is made available under a CC-BY 4.0 International license .

Table 1. GWAS used for two sample Mendelian Randomisation.

\begin{tabular}{|c|c|c|c|c|c|}
\hline Phenotype & Reference & $\begin{array}{l}\text { Consortium or } \\
\text { sample }\end{array}$ & $\begin{array}{l}\text { Excluded } \\
\text { samples }\end{array}$ & $\begin{array}{l}\text { Final } \\
\text { sample } \\
\text { size }\end{array}$ & $\begin{array}{l}\mathrm{R}^{2} \text { and SNP } \\
\text { heritability }\end{array}$ \\
\hline $\begin{array}{l}\text { Smoking } \\
\text { initiation } \\
\text { (ever/never) }\end{array}$ & $\begin{array}{l}\text { Liu et al, } \\
2019 \text { (23) }\end{array}$ & $\begin{array}{l}\text { GSCAN } \\
\text { (23andMe, } \\
\text { ALSPAC, ARIC, } \\
\text { BEAGESS, BLTS, } \\
\text { CADD, COGEND, } \\
\text { COPDGene, } \\
\text { deCODE, } \\
\text { EGCUT, FHS, } \\
\text { FinnTwin, GERA, } \\
\text { GfG, Harvard, } \\
\text { HRS, HUNT, } \\
\text { MCTFR, MESA, } \\
\text { METSIM, } \\
\text { NESCOG, NAG- } \\
\text { FIN, NTR, QIMR, } \\
\text { SardiNIA, UK } \\
\text { Biobank, WHI) }\end{array}$ & $\begin{array}{l}\text { Dependent on } \\
\text { analysis, } \\
\text { published GWAS } \\
\text { summary } \\
\text { statistics were } \\
\text { used other than } \\
\text { for analyses with } \\
\text { outcomes for i) } \\
\text { cannabis use } \\
\text { where only the } \\
\text { 23andMe } \\
\text { sample was } \\
\text { included and ii) } \\
\text { drinks per week } \\
\text { where 23andMe } \\
\text { was excluded. }\end{array}$ & $\begin{array}{l}\text { All } \\
\text { samples = } \\
1,232,091 \\
\text { i) } \\
\text { cannabis } \\
\text { use = } \\
599,289 \\
\text { ii) drinks } \\
\text { per week } \\
=632,802\end{array}$ & $\begin{array}{l}\mathrm{R}^{2}=2.32 \% \\
\mathrm{~h}^{2}=7.8 \%\end{array}$ \\
\hline $\begin{array}{l}\text { Drinks per } \\
\text { week }\end{array}$ & $\begin{array}{l}\text { Liu et al, } \\
2019 \text { (23) }\end{array}$ & GSCAN & $\begin{array}{l}\text { Dependent on } \\
\text { analysis, } \\
\text { published GWAS } \\
\text { summary } \\
\text { statistics were } \\
\text { used other than } \\
\text { for analyses with } \\
\text { outcomes for i) } \\
\text { cannabis use } \\
\text { where only the } \\
\text { 23andMe } \\
\text { sample was } \\
\text { included. }\end{array}$ & $\begin{array}{l}\text { All } \\
\text { samples= } \\
941,280 \\
\text { i) } \\
\text { cannabis } \\
\text { use = } \\
403,931\end{array}$ & $\begin{array}{l}R^{2}=0.19 \% \\
h^{2}=4.2 \%\end{array}$ \\
\hline $\begin{array}{l}\text { Cannabis } \\
\text { use } \\
\text { (ever/never) }\end{array}$ & $\begin{array}{l}\text { Pasman } \\
\text { et al, } \\
2018(41)\end{array}$ & $\begin{array}{l}\text { ICC (ALSPAC, } \\
\text { BLTS, CADD, } \\
\text { EGCUT1, } \\
\text { EGCUT2, } \\
\text { FinnTwin, } \\
\text { HUVH, MCTFR, } \\
\text { NTR, QIMR, } \\
\text { TRAILS, Utrecht, } \\
\text { Yale Penn EA), } \\
\text { UK Biobank and } \\
\text { 23andMe }\end{array}$ & 23andMe & 162,082 & $\begin{array}{l}R^{2}=0.15 \% \\
h^{2}=11 \%\end{array}$ \\
\hline
\end{tabular}




\begin{tabular}{|c|c|c|c|c|c|}
\hline $\begin{array}{l}\text { Cannabis } \\
\text { dependence }\end{array}$ & $\begin{array}{l}\text { Agrawal } \\
\text { et al, } \\
2017(42)\end{array}$ & $\begin{array}{l}\text { CATS, COGA-CC, } \\
\text { COGA-f, OZALC, } \\
\text { SAGE }\end{array}$ & NA & $\begin{array}{l}2,080 \\
\text { cases and } \\
6,435 \\
\text { exposed } \\
\text { controls }\end{array}$ & $\begin{array}{l}\text { Not } \\
\text { reported }\end{array}$ \\
\hline $\begin{array}{l}\text { Cocaine } \\
\text { dependence } \\
\text { (DSM-IV } \\
\text { criteria) }\end{array}$ & $\begin{array}{l}\text { Gelernter } \\
\text { et al, } \\
2014(43)\end{array}$ & $\begin{array}{l}\text { Yale (APT } \\
\text { Foundation), } \\
\text { University of CT, } \\
\text { MUSC, McLean } \\
\text { Hospital, } \\
\text { University of } \\
\text { Pennsylvania }\end{array}$ & NA & $\begin{array}{l}1,809 \\
\text { cases and } \\
292 \\
\text { exposed } \\
\text { controls }\end{array}$ & $\begin{array}{l}\text { Not } \\
\text { reported }\end{array}$ \\
\hline $\begin{array}{l}\text { Opioid } \\
\text { dependence } \\
\text { (DSM-IV } \\
\text { criteria) }\end{array}$ & $\begin{array}{l}\text { Gelernter } \\
\text { et al, } \\
2014(44)\end{array}$ & $\begin{array}{l}\text { Yale (APT } \\
\text { Foundation), } \\
\text { University of CT, } \\
\text { MUSC, McLean } \\
\text { Hospital, } \\
\text { University of } \\
\text { Pennsylvania }\end{array}$ & NA & $\begin{array}{l}1,383 \\
\text { cases and } \\
366 \\
\text { exposed } \\
\text { controls }\end{array}$ & $\begin{array}{l}\text { Not } \\
\text { reported }\end{array}$ \\
\hline
\end{tabular}

${ }^{1}$ The $r^{2}$ reported was for genome-wide significant SNPs only and the SNP heritability $\left(h^{2}\right)$ was for all SNPS. GSCAN= GWAS \& Sequencing Consortium of Alcohol and Nicotine use, ALSPAC=Avon Longitudinal Study of Parents and Children, $A R I C=$ Atherosclerosis Risk in Communities, BEAGESS=The Barrett's and Esophageal Adenocarcinoma Genetic Susceptibility Study, BLTS=Brisbane Longitudinal Twin Study, CADD=Center on Antisocial Drug Dependence, COGEND=Collaborative Genetic Study of Nicotine Dependence, COPDGene=Genetics of Chronic Obstructive Pulmonary Disease, EGCUT=Estonian Genome Center, FHS=Framingham Heart Study, FinnTwin and NAG-FIN =Finnish Twin Cohort, GERA=Genetic Epidemiology Research in Adult Health and Aging, GfG=Genes for Good, Harvard, HRS=Health and Retirement Study, HUNT=The Nord-Trøndelag Health Study, MCTFR=Minnesota Center for Twin and Family Research, MESA=Multi-Ethnic Study of Atherosclerosis, METSIM=Metabolic Syndrome in Men, NESCOG=Netherlands Study on Cognition, Environment and Genese, NTR=Netherlands Twin Register, WHI=Women's Health Initiative, COGA = Collaborative Study on the Genetics of Alcoholism, SAGE= Study of Addictions: Genes and Environment, OZALC = Australian Alcohol, Nicotine Addiction Genetics and Childhood Trauma, CATS= Comorbidity and Trauma Study. 
medRxiv preprint doi: https://doi.org/10.1101/2021.01.12.21249649; this version posted August 5, 2021. The copyright holder for this preprint (which was not certified by peer review) is the author/funder, who has granted medRxiv a license to display the preprint in It is made available under a CC-BY 4.0 International license .

Figure 1. Bidirectional two-sample Mendelian randomisation between smoking initiation/alcohol consumption and illicit substance use outcomes

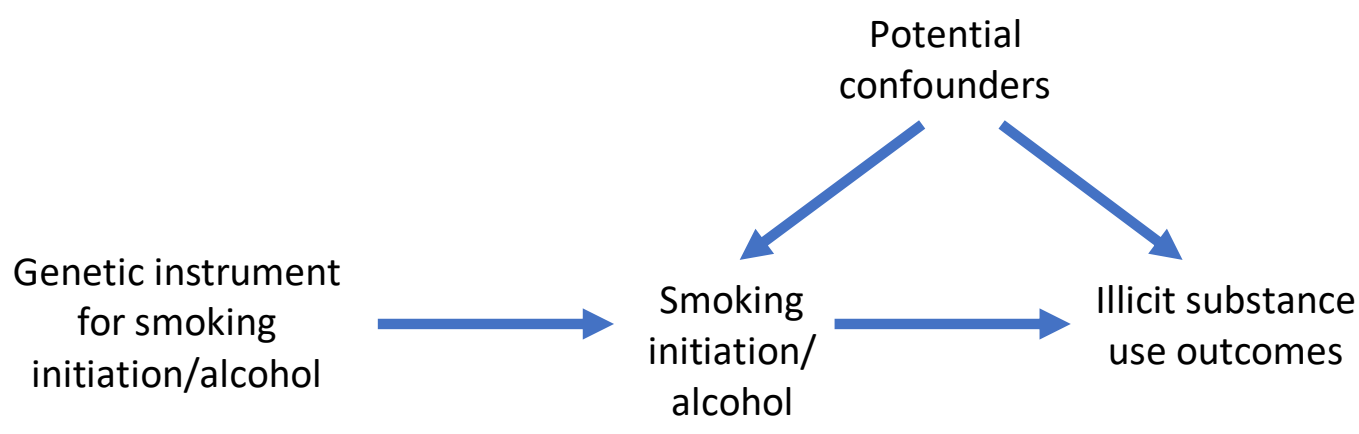

A directed acyclic graph (DAG) for the causal effect between smoking initiation/alcohol consumption and illicit substance use outcomes. Evidence of a causal effect in the other direction may indicate a bidirectional effect, or a common underlying risk factor.

Figure 2. Forest plot for two-sample Mendelian randomisation with smoking initiation as the exposure

Exposure
Smoking Initiation
Exposure
Smoking Initiation
Smoking Initiation
Smoking Initiation
Smoking Initiation

Outcome
Drinks per week
Outcome
Cannabis use
Cannabis dependence
Cocaine dependence
Opioid dependence

\begin{tabular}{rr}
\multicolumn{1}{c}{$\begin{array}{r}\text { N SNPs } \\
72\end{array}$} & $\begin{array}{r}\text { Beta }(95 \% \mathrm{Cl}) \\
0.06(0.03 \text { to } 0.09)\end{array}$ \\
N SNPs & OR (95\% Cl) \\
144 & $1.34(1.24$ to 1.44$)$ \\
133 & $1.68(1.12$ to 2.51$)$ \\
190 & $1.21(0.58$ to 2.53$)$ \\
155 & $1.41(0.62$ to 3.20$)$
\end{tabular}
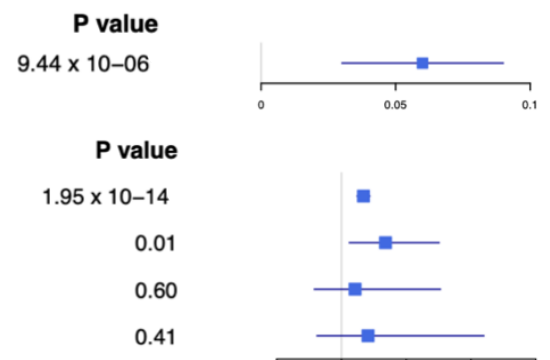

Causal effects from the inverse-variance weighted Mendelian randomisation method where smoking initiation is the exposure. Effect estimates are presented as beta or odds ratios (OR) depending on whether the outcome was continuous or binary, with 95\% confidence intervals (CI). SNP=single nucleotide polymorphism. 
medRxiv preprint doi: https://doi.org/10.1101/2021.01.12.21249649; this version posted August 5, 2021. The copyright holder for this preprint (which was not certified by peer review) is the author/funder, who has granted medRxiv a license to display the preprint in It is made available under a CC-BY 4.0 International license.

Figure 3. Forest plot for two-sample Mendelian randomisation with smoking initiation as the outcome

Exposure
Drinks per week
Cannabis use
Cannabis dependence
Cocaine dependence
Opioid dependence

Outcome
Smoking Initiation
Smoking Initiation
Smoking Initiation
Smoking Initiation
Smoking Initiation

$\begin{array}{rr}\text { N SNPs } & \text { OR }(95 \% \mathrm{Cl}) \\ 22 & 1.26(0.92 \text { to } 1.72) \\ 4 & 1.39(1.08 \text { to } 1.80) \\ 9 & 1.00(0.99 \text { to } 1.01 \\ 27 & 1.00(1.00 \text { to } 1.00) \\ 7 & 1.00(0.99 \text { to } 1.01)\end{array}$

P value
0.15
0.01
0.60
0.42
0.80

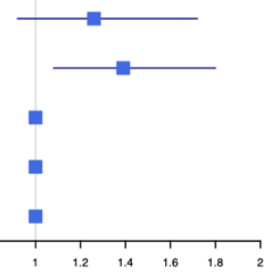

Causal effects from the inverse-variance weighted Mendelian randomisation method where smoking initiation is the outcome. Effect estimates are presented as odds ratios (OR) with 95\% confidence intervals $(\mathrm{Cl})$.

SNP=single nucleotide polymorphism.

Figure 4. Forest plot for two-sample Mendelian randomisation with drinks per week as the exposure

\begin{tabular}{|c|c|c|c|c|c|}
\hline Exposure & Outcome & N SNPs & OR $(95 \% \mathrm{Cl})$ & $P$ value & \\
\hline Drinks per week & Cannabis use & 20 & 0.55 (0.16 to 1.93$)$ & 0.35 & $=$ \\
\hline Drinks per week & Cannabis dependence & 41 & 2.73 (0.62 to 11.95$)$ & 0.18 & \\
\hline Drinks per week & Cocaine dependence & 68 & 0.50 (0.09 to 2.79$)$ & 0.43 & $=$ \\
\hline Drinks per week & Opioid dependence & 47 & 0.38 (0.06 to 2.41$)$ & 0.30 & $=$ \\
\hline
\end{tabular}

Causal effects from the inverse-variance weighted Mendelian randomisation method where drinks per week is the exposure. Effect estimates are presented as odds ratios (OR) with 95\% confidence intervals (CI).

$S N P=$ single nucleotide polymorphism.

Figure 5. Forest plot for two-sample Mendelian randomisation with drinks per week as the outcome 
medRxiv preprint doi: https://doi.org/10.1101/2021.01.12.21249649; this version posted August 5, 2021. The copyright holder for this preprint (which was not certified by peer review) is the author/funder, who has granted medRxiv a license to display the preprint in perpetuity.
It is made available under a CC-BY 4.0 International license .

Exposure
Cannabis use
Cannabis dependence
Cocaine dependence
Opioid dependence

Opioid dependence

$\begin{array}{rr}\text { Outcome } & \text { N SNPs } \\ \text { Drinks per week } & 22 \\ \text { Drinks per week } & 4 \\ \text { Drinks per week } & 9 \\ \text { Drinks per week } & 27\end{array}$

27

Beta $(95 \% \mathrm{Cl})$
$0.03(-0.009$ to 0.07$)$
$-0.0003(-0.003$ to 0.002$)$
$0.0007(-0.0007$ to 0.001$)$
$0.002(0.0005$ to 0.002$)$

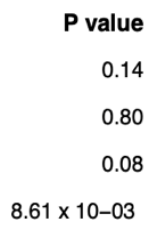

Causal effects from the inverse-variance weighted Mendelian randomisation method where drinks per week is the outcome. Effect estimates are presented as beta with 95\% confidence intervals (CI). $S N P=$ single nucleotide polymorphism. 